\title{
УДК 340
}

DOI https://doi.org/10.32840/1813-338X-2020.1-1.3

\author{
Д. Г. Манько \\ кандидат юридичних наук, доцент, \\ доцент кафедри державно-правових дисциплін \\ Міжнародного гуманітарного університету
}

\section{ДІДЖИТАЛІЗАЦІЯ ПРАВОВОГО РЕГУЛЮВАННЯ: ТЕХНОЛОГІЧНІ АЛГОРИТМИ Й ЕЛЕКТРОННІ ДОКУМЕНТИ}

Сучасне право відображає наявний рівень свободи, воно інтерактивне, динамічне і певною мірою гнучке. Воно відкрите до збагачення зовнішніми фракторами, воно корелює з правовими традиціями й відповідає вимогам часу, але залишається незмінним у своїй сутностізабезпеченні захисту й належної реалізації свободи індивідів.

Нині монополія жорсткого права відступає під розширенням ролі в регулюванні суспільних відносин м'яким правом. Світова спільнота переосмислює роль забезпечених примусом санкцій щодо фрактичних інтересів і волі сторін конфрлікту в напрямі його фрактичного вирішення. Відома фрормула отримує нову фрорму розвитку: важливим є результат, який задовольняє інтереси не лише сторін конфрлікту, а й не суперечить загальним вимогам світового співтовариства та правам і свободам індивідів.

Поряд із цим слід враховувати, що досягнення зазначених орієнтирів є можливим лише у відповідному середовищі. На нашу думку, таким середовищем є сучасна держава. Стійка, відкрита до співпраці з іншими країнами, з ефективним механізмом і належним рівнем діджиталізації.

Зазначені складні процеси вимагають високого рівня юридично-технологічної регламентації процедурно-процесуального механізму їх здійснення. Особливого значення набувають ті алгоритми (технологічна досконалість, відповідність інструментарію галузі регулювання, законність, обгрунтованість, своєчасність, переконливість тощо), які закріплюються в письмових правових актах.

Аналізуючи наявні алгоритми правового регулювання, ми стикаємося з певною методологічною проблемою щодо класифрікації. У зазначеному аспекті, необхідно враховувати нетотожність таких термінопонять, як юридичний алгоритм (legal algorithm), алгоритми права (algorithms of law), технологічні алгоритми в праві (technology algorithms in law).

Технологічні алгоритми в праві слід розглядати як сукупність техніко-технологічних продуктів (електронні документи, електронний иифровий підпис, комп'ютерні програми, пошукові бази даних, електронні реєстри, електронні площадки вирішення спорів, юридичні боти та інше), які використовуються в юриспруденції.

Своєю чергою стрімкий розвиток суспільних відносин в епоху постмодерну, динаміка технологічного розвитку й процесів обміну інформацією обумовлюють особливе становище й роль електронного документа в сучасній системі документообігу.

Ключові слова: діджиталізація в правовій сорері, транспарентність, юридичний алгоритм, технологічні алгоритми права, електронний документообіг, електронний документ.

Постановка проблеми. Враховуючи стрімкий розвиток суспільних відносин і значний вплив інфрормаційно-технологічних процесів на правову сфреру, особливо актуальними для загальнотеоретичної юриспруденції стають дослідження технологічних алгоритмів права й електронних документів як складових елементів процесів діджиталізації правового регулювання суспільних відносин у сучасній державі.

Аналіз останніх досліджень і публікацій. Упродовж останніх років особливу увагу в загальнотеоретичній юриспруденції приділено питанням, пов'язаним 3 особливостями організації й фрункціонування сучасної держави та права, оцінки впливу інформаційно-технологічних процесів на їх існування. Серед учених, які зробили помітний внесок у цій царині, варто назвати О. О. Джураєву, Н. М. Крестовську, О. М. Лощихіна, С. І. Максимова, Ю. М. Оборотова, Н. М. Оніщенко, С. П. Погребняка та інших.

Мета статті. Теоретико-правовий аналіз ролі технологічних алгоритмів й електронних 
документів у процесах діджиталізації правового регулювання.

Виклад основного матеріалу. Правове регулювання в сучасній державі має відбуватися з застосуванням цілісної системи засобів, які підпорядковані головній меті - забезпеченню реалізації й захисту прав і свобод індивідів. Указані засоби мають бути досконалими не лише з точки зору вимог юридичної техніки й технологій, але й відповідати потребам і інтересам суспільства, в тому числі й з урахуванням розвитку інформаційно-технологічних і комунікативних процесів.

Н. М. Крестовська цілком слушно зазначає, що «риси сучасної держави не тільки зафіксовані в системі нормативних вимог, але й виражені в реальному ії бутті. У вигляді конкретних державних інститутів, їх організації та функціонування. Сучасна держава - це результат зміни менталітету людей, сприйняття не тільки колишніх традицій державності, але й використання загальнолюдських цінностей і змін у сучасному світі» [3, с. 257].

Своєю чергою Ю. М. Оборотов, аналізуючи сутність сучасної держави, підкреслює важливість спроможності держави адаптуватися до викликів сьогодення. Зокрема, вказуючи, що «стійкість держави залежить не тільки й не стільки від організації держави, її інституціоналізації, скільки від тих цінностей і цілей, якими керуються правителі та підвладні, які неминуче «форматують» нормативні приписи, створюючи на їхній базі специфрічні форми професійної активності. Від того, наскільки культурно обумовлені комунікативні зв'язки, спроможні адаптувати державу до змін у зовнішньому і внутрішньому середовищі, залежить не тільки сьогоднішнє буття держави, а і іï подальше життя або загибель» [5, с. 226].

Отже, ми можемо дійти висновку, що сучасна держава має наступні ключові характеристики: орієнтованість на створення належних умов реалізації та захисту прав і свобод індивідів, стійкість, відкритість до співпраці з іншими суб'єктами, ефрективний механізм реалізації функцій і належний рівень діджиталізації.

Щодо останньої характеристики, то тут слід враховувати кілька важливих аспектів. Так, на сьогодні існують кілька варіантів визначення цього терміну. Одним з найбільш ґрунтовних вбачається такий, де діджиталізацію розуміють як неологізм, який увійшов в українську мову лише кілька років тому, є транслітерацією англійського digitalization і згідно з визначенням словника означає зміни в усіх сферах суспільного життя, пов'язанні 3 використанням цифрових технологій. Зазначене слово $є$ спрощеною формою точнішого терміну «цифррова трансформація» таєпроявом глобальної цифрової революції» [1].

Щодо розвитку програми діджиталізації в Україні уряд прийняв Положення про Міністерство цифрової трансформації України (Мінцифри), яке було затверджено Постановою Кабінету Міністрів України № 856 від 18 вересня 2019 р. Зазначений акт створює правові передумови для фрункціонування цієї інституції, визначає засади, цілі та принципи ії діяльності.

Зокрема в указаному документі визначено, що «Мінцифри забезпечує: фрормування та реалізацію державної політики у сфрері цифровізації, цифрової економіки, цифрових інновацій, електронного урядування та електронної демократії, розвитку інфрормаційного суспільства; формування та реалізацію державної політики у сфрері розвитку цифррових навичок та цифрових прав громадян; формування та реалізацію державної політики у сфері відкритих даних, розвитку національних електронних інформаційних ресурсів й інтероперабельності, розвитку інфрраструктури широкосмугового доступу до Інтернету та телекомунікацій, електронної комерції та бізнесу; формування та реалізацію державної політики у сфері надання електронних та адміністративних послуг; формування та реалізацію державної політики у сфері електронних довірчих послуг; фрормування та реалізацію державної політики у сфрері розвитку IT-індустрії; виконання функцій центрального засвідчувального органу шляхом забезпечення створення умов для функціонування суб'єктів правових відносин у сфері електронних довірчих послуг» [11].

Невід'ємною складовою діджиталізації сучасної держави $є$ процеси транспарентності організації та діяльності ії механізму.

Аналізуючи поняття транспарентності, Л. Р. Наливайко та М. Ю. Романов зазначають, що це «складна теоретико-правова категорія, яка змістовно поєднує в собі такі поняття, як прозорість, відкритість, гласність, публічність, підзвітність, доступ до публічної інформації й участь в управлінні державними справами. Також належить погодитися з тим, що прозорість - це обізнаність у діях влади, а відкритість - це реальна можливість впливу, але з цього виходить, що, керуючись напрацюваннями вчених, які уніфрікують ці складові в категорію транспарентності, ми не лише спростимо понятійно-категоріальний апарат у сфері вза- 
ємодії громадськості й державної влади, але й відкриємо нове поле для наукової дискусії, що може сприяти розвитку демократичної та соціальної держави в Україні» [4, с. 29].

На думку С. О. Верланова, «транспарентність - це не вимога, це вже наша реальність. Наприклад, у податковій службі безліч процесів, які були аналоговими й вимагали паперової роботи, пішли в минуле. Поступовий перехід на сервісну службу з мінімізацією спілкування бізнесу й податкових органів давно вже став пріоритетним завданням служби. Транспарентність вирішує багато питань і дає змогу автоматизувати більшість процесів» [2].

Зазначені складні процеси вимагають високого рівня юридично-технологічної регламентації процедурно-процесуального механізму їх здійснення. У зазначеному аспекті особливого значення набувають ті алгоритми (їх технологічна досконалість, відповідність інструментарію галузі регулювання, законність, обґрунтованість, своєчасність, переконливість тощо), які закріплюються в письмових правових актах.

Аналізуючи наявні алгоритми правового регулювання, ми стикаємося з певною методологічною проблемою щодо їх класифрікації. У зазначеному аспекті необхідно враховувати нетотожність таких термінопонять: юридичний алгоритм (legal algorithm), алгоритми права (algorithms of law), технологічні алгоритми в праві (technology algorithms in law).

Розглянемо зазначені поняття детальніше. Юридичний алгоритм $є$ закріпленою в письмовому правовому акті специфічною юридичною конструкцією, в якій виражено соціально значуще правило поведінки. Це правило має обов'язковий до виконання характер і забезпечено правовими засобами. Стосовно традиційної в континентальній правовій сім'ї концепції розуміння системи права юридичний алгоритм закріплюється в динамічних диспозиціях норм права або інших основних частин правових актів і $€$ дієвим інструментом конкретизації загальних правових приписів.

У юридичному алгоритмі відображено певну послідовність діянь (дія або бездіяльність), які має або може вчинити визначена особа, або обсяг позбавлень чи наділень певними цінностями такої особи.

Наявність юридичних алгоритмів $€$ необхідною засадою забезпечення якісного й ефективногоправовогорегулювання суспільнихвідносин і реалізації функцій права. Юридичний алгоритм $є$ закріпленою в письмовому правовому акті специфрічною юридичною конструкцією, в якій виражено соціально значуще правило поведінки у вигляді чіткої послідовності діянь суб'єкта права. Таке правило поведінки забезпечено правовими засобами. Це закріплена в правовому акті модель легальної активності суб'єктів права, а відповідно основа динаміки права, його реального впливу на суспільні відносини.

Враховуючи зазначені характеристики, під юридичним алгоритмом слід розуміти закріплену в типовому правовому акті (м'якого або жорсткого права) юридичну конструкцію зобов'язального волевиявлення, якою чітко регламентується, хто, в якому порядку й що має зробити або утриматися від дій або обсяг позбавлень чи наділень певними цінностями такої особи.

Поміж інших ознак особливу увагу слід приділяти закріпленості в типовому правовому акті. Враховуючи природу правових приписів, диспозиція правової норми або основна частина іншого виду правових актів (положень, наказів, договорів тощо) може бути двох типів: статична диспозиція для спеціалізованих (нетипових) норм права (наприклад, норми засади: ст. 2 Конституції України визначає Україну «як унітарну державу») або основної частини іншого виду правових актів (приміром, резолютивна частина наказу: наказую «використовувати приміщення зимового саду як кімнату для відпочинку») містить характеристику статусу певного суб'єкта або режим використання об'єкта, визначення теоретичного значення певного термінопоняття та інше; динамічна диспозиція для класичних (типових) норм права (приміром, у п. 49.3 ст. 49 Податкового кодексу України вказується, що «податкова декларація подається особисто платником податків або уповноваженою на це особою» [6]) містить послідовний порядок поведінки й персоніфрікацію суб'єкта.

Отже, юридичний алгоритм слід розглядати виключно як юридичну конструкцію, складову частину окремих видів правових актів. Інакше кажучи, юридичний алгоритм $\epsilon$ те, що прямо прописано в тексті правового акту й містить у собі такі складові, як персоніфікація та модель поведінки.

Своєю чергою алгоритми права - це певний рівень теоретичного узагальнення, який відображає характеристику окремих і таких, що системно повторюються у правовій площині, процесів. Приміром, «демократія досягається через верховенство права», або протилежна концепція: «закон - це інструмент підкорення підвладних суб'єктів», або аксіоматичні поло- 
ження: «суб'єктивному праву завжди відповідає юридичний обов'язок», «не заборонена нормами й принципами права поведінка дозволяється» тощо. Алгоритми права не персоніфіковані, вони містять загальну модель поведінки. Таким чином, алгоритми права слід розглядати як одну з особливих науково-правових категорій, елемент категоріального апарату загальнотеоретичної юриспруденції.

Але в сучасному світі особливе місце посідають інформаційно-технологічні процеси. Організаціяй управліннязазначенимипроцесамиздійснюєтьсязадопомогоютехнологічнихалгоритмів.

На думку Джеремі Баррета, «під технологічними алгоритмами слід розуміти поєднання програмної й апаратної складової з можливостями штучного інтелектуального розвитку, направлене на досягнення встановлених цілей. До основних технологічних алгоритмів відносять:

- штучний інтелект (Artificial Intelligence) системи машинного навчання, здатні виконувати завдання, які зазвичай вимагають інтелекту людини;

- технології блокчейну (Blockchain Technologies) - технологія, що лежить в основі цифрових валют і транзакцій, яка забезпечує, перевіряє й обробляє дані транзакцій;

- Інтернет речей (Internet of Things) - це система взаємопов'язаних на основі Інтернету різноманітних «розумних» фізичних пристроїв, транспортних засобів, будівель тощо, які дають змогу цим об'єктам збирати й обмінюватися даними;

- поведінкова й прогнозована аналітика (Behavioural and Predictive Analytics) - аналіз великих і різноманітних наборів даних для виявлення прихованих моделей, невідомих кореляцій, уподобань клієнтів тощо, щоб допомогти приймати обґрунтовані рішення» [14].

Ці чотири технології тісно пов'язані між собою: штучний інтелект забезпечує алгоритми, блокує ланцюг інфраструктури зберігання й оброблення даних, Інтернет речей і поведінкова / прогностична аналітика важливі для аналізу поведінки людини.

3 цього приводу Д. Десай і Д. Крол указують, що «краще розуміння того, як працюють програми і як комп'ютерні фрахівці працюють з обмеженнями своєї області, створює інструменти для управління світом і розвиває використання алгоритмів і законів. Це своєю чергою дає змогу суспільству враховувати інтереси правосуддя й безпеки, а також допомагає багатьом учасникам використовувати ці нові методи для інновацій і поліпшення світу, в якому ми живемо» [13].
Враховуючи зазначене, технологічні алгоритми в праві слід розглядати як сукупність техніко-технологічних продуктів (електронні документи, електронний цифровий підпис, комп'ютерні програми, пошукові бази даних, електронні реєстри, електронні площадки вирішення спорів, юридичні боти та інше), які використовуються в юриспруденції.

Стрімкий розвиток суспільних відносин в епоху постмодерну, динаміка технологічного розвитку й процесів обміну інформацією обумовлюють особливе положення та роль електронного документа в системі документообігу сучасності.

Слід погодитися з думкою Ю. Н. Харарі щодо ролі й місця інфрормаційних технологій у розвитку майбутніх відносин у суспільстві. Зокрема науковець зазначає: «Датаїзм наголошує, що Всесвіт складається з потоків даних і що цінність будьякого явища або сутності визначається їхнім вкладом в обробку даних. Датаїзм наголошує, що біохімічні та електронні алгоритми підкорюються тотожним математичним законам. Більш того, створення й обробка даних має бути довірена електронним алгоритмам» [12, с. 431].

Юридичні технології створення електронних документів насамперед пов'язанні з наявністю в суб'єкта знань у сфрері інфрормаційних технологій і вміння працювати на персональному комп'ютері.

Сьогодні кожен юрист - це професійний споживач інформаційно-комунікативних технологій (ІКТ) і систем. Уявити юриста без персонального комп'ютера, мобільного телефрону та інших технічних аксесуарів просто неможливо.

Очевидно, що юрист повинен знати, як можна застосувати IКТ у своїй роботі та які правові інформаційні системи вже створено й упроваджено. Правові інфрормаційні системи інтегровані в загальну систему проєктного документообігу та $\epsilon$ величезною допомогою для молодих юристів, які набувають досвіду.

Але незалежно від майбутнього місця роботи юристу необхідні знання про комп'ютерні технології загалом, про тенденції комп'ютеризації й інфоорматизації, про інформаційні системи підприємницьких фрірм, банків, органів державної влади тощо. Без цього юрист не може ефективно виконувати свої функції.

Одним із важливих результатів використання технологічних алгоритмів у праві $\epsilon$ створення електронних документів. Юридична діяльність відбувається за допомогою документів, які одночасно $€$ джерелом, результатом і інструментом 
цієї діяльності. Сьогодні документ є основним способом подання інформації на будь-якому рівні суспільних відносин.

Згідно з Законом України «Про інформацію» від 2 жовтня 1992 р. документ - це матеріальний носій, що містить інформацію, основними фрункціями якого $є$ ії̈ збереження й передавання в часі й просторі [10].

Більш розгорнуте визначення документа містить такі положення: це матеріальна форма одержання, зберігання, використання й поширення інформації, зафіксованої на папері, магнітній, кіно- й фотоплівці, оптичному диску або іншому носії.

У ст. 5 Закону України «Про електронні документи та електронний документообіг» зазначається, що «електронний документ - документ, інформація в якому зафріксована у вигляді електронних даних, включаючи обов'язкові реквізити документа» [8].

До обов'язкових реквізитів належить електронний підпис: «це електронні дані, які додаються підписувачем до інших електронних даних або логічно з ними пов'язуються й використовуються ним як підпис» [7].

Наявність валідних складових елементів електронного документа підтверджують його юридичну силу.

Так, у ст. 8 Закону України «Про електронні документи та електронний документообіг» зазначено, що «юридична сила електронного документа не може бути заперечена тільки через те, що він має електронну форму. Проте встановлюються й певні обмеження на застосування електронного документа як оригіналу. В електронній формі не може бути створено оригінал свідоцтва про право на спадщину; документ, який відповідно до законодавства може бути створений лише в одному примірнику, крім випадків існування централізованого сховища оригіналів електронних документів» [8].

Особливості юридичних технологій щодо користування електронними документами проявляються в процесах електронного документообігу. «Електронний документообіг (обіг електронних документів) - сукупність процесів створення, оброблення, відправлення, передавання, одержання, зберігання, використання та знищення електронних документів, які виконуються з застосуванням перевірки цілісності та в разі необхідності з підтвердженням фракту одержання таких документів» [8].

Алгоритми електронного документообігу встановлюються державними органами, орга- нами місцевого самоврядування, підприємствами, установами й організаціями всіх форм власності згідно з законодавством.

Електронний документообіг здійснюється відповідно до законодавства України чи на підставі договорів, що визначають взаємовідносини суб'єктів електронного документообігу. Використання електронного документа в цивільних відносинах здійснюється згідно з загальними вимогами до правочинів, установлених цивільним законодавством.

Правовим актом, в якому визначено порядок застосування електронного документа й електронного підпису в органах державної влади України, є Постанова Кабінету Міністрів України «Про затвердження Порядку використання електронних довірчих послуг в органах державної влади, органах місцевого самоврядування, підприємствах, установах та організаціях державної фрорми власності» від 19 вересня 2018 р. У цьому акті зокрема зазначено, що «кожний електронний документ, який одержує адресат, перевіряється на зараження його вірусом, на цілісність і справжність усіх накладених на нього електронних цифррових підписів, включаючи ті, що накладені (проставлені) згідно з законодавством як електронні печатки» [9].

Слід звернути увагу, що під час накладання кваліфрікованого електронного підпису чи печатки обов'язковим $є$ використання електронної позначки часу.

У електронному документообігу державних органів особливе місце посідає кваліфікована електронна печатка, яка застосовується для верифрікації цілісності електронних даних, а також ідентифрікації державної установи як підписувача, у тому числі для засвідчення відповідності електронних копій електронного й паперового (фотокопія) документів оригіналу у випадках, передбачених законодавством.

Висновки і пропозиції. Підсумовуючи, слід зазначити, що технологічні алгоритми в праві $\epsilon$ відображенням процесів діджиталізації відносин правової сфрери в сучасній державі. Безумовно, багатопитаньщемаютьбутивирішені, алезагальний напрям розвитку заслуговує на підтримку й подальші загальнотеоретичні дослідження.

\section{Список використаної літератури:}

1. «Діджиталізація» - слово 2019 року в Україні за версією онлайн-словника «Мислово». URL: https://itc.ua/news/didzhitalizacziya-slovo2019-roku-v-ukra\%D1\%97ni-za-versi\%D1\% 94yu-onlajn-slovnika-mislovo/. 
2. Вища рада правосуддя. Нові світові стандарти у сфері правового регулювання формують транспарентність та діджиталізація. URL: https://hcj.gov.ua/news/novi-svitovi-standartyu-sferi-pravovogo-regulyuvannya-formuyuttransparentnist-ta.

3. Крестовська Н. М. Нові підходи до типології держави. Актуальні грані загальнотеоретичної юриспруденції : монографія. Одеса. 2012. Підрозд. 3.9. С. 256-268.

4. Наливайко Л., Романов М. Поняття та ознаки транспарентності в контексті євроінтеграції. Jurnalul juridic national: teorie şi practică. 2016. № 5 (21). C. 27-29.

5. Оборотов Ю. Н. Содержание аксиосферы государства. Актуальні проблеми держави і права. 2008. Вип. 40. С. 223-231.

6. Податковий кодекс України : Закон України від 2 грудня 2010 р. №2755-VI / Верховна Рада України. URL: http://zakon2.rada.gov.ua/laws/ show/1798-19.

7. Про електронні довірчі послуги : Закон України від 5 жовтня 2017 р. № 2155-VIII / Верховна Рада України. URL: https://zakon.rada.gov.ua/ laws/show/2155-19.

8. Про електронні документи та електронний документообіг : Закон України від 22 травня
2003 р. № 851-IV / Верховна Рада України. URL: https://zakon.rada.gov.ua/laws/show/851-15.

9. Про затвердження Порядку використання електронних довірчих послуг в органах державної влади, органах місцевого самоврядування, підприємствах, установах та організаціях державної форми власності : Постанова від 19 вересня 2018 р. / Кабінет Міністрів України. URL: https://zakon.rada.gov.ua/laws/ show/749-2018-\%D0\%BF.

10.Про інформацію : Закон України від 2 жовтня 1992 р. № 2657-XII / Верховна Рада України. URL: https://zakon.rada.gov.ua/laws/ show/2657-12.

11. Урядовий портал. Питання Міністерства цифрровоїтрансформації.URL:https://www.kmu.gov.ua/ npas/pitannya-ministerstva-cifrovoyi-t180919.

12.Харари Ю. Н. Homo Deus. Краткая история будущего. Москва : Синдбад, 2016. 520 с.

13.Deven R. Desai, Joshua A. Kroll. Trust but verify: a guide to algorithms and the law. URL: https://jolt.law.harvard.edu/assets/articlePDFs/ v31/31HarvJLTech1.pdf.

14.Jeremy Barnett, Adriano Soares Koshiyama and Philip Treleaven. Algorithms and the Law. URL: http://www.jeremybarnett.co.uk/algorithms-andthe-law.

\section{Manko D. G. Digitalization of legal regulation: technology algorithms and electronic documents}

Modern law reflects the existing level of freedom, it is interactive, dynamic and, to some extent, flexible. It is open to enrichment by external factors, it correlates with legal traditions and meets the requirements of the times, but the right remains intact - ensuring the protection and proper enjoyment of the freedom of individuals.

Today, the hard-law monopoly is giving way to a broader role in regulating social relations by soft law. The world community is rethinking the role of coercive sanctions in their relation to the actual interests and will of the parties to the conflict in the direction of its actual resolution. The well-known formula takes on a new form of development - an important outcome that satisfies the interests not only of the parties to the conflict, but also does not contradict the general requirements of the world community and the rights and freedoms of individuals.

In addition, it should be borne in mind that the achievement of these guidelines is possible only in the right environment. In our opinion, such an environment is a modern state. Resilient, open to cooperation with other countries, with an effective mechanism and proper level of digitization.

These complex processes require a high level of legal and technological regulation of procedural and procedural mechanism of their implementation. In this aspect, particular importance is given to those algorithms (their technological perfection, compliance with regulatory instruments, legality, validity, timeliness, persuasiveness, etc.), which are enshrined in written legal acts.

However, when analyzing existing regulatory algorithms, we face some methodological problems regarding their classification. In this aspect, it is necessary to take into account the identity of such terms as: legal algorithm, algorithms of law, technology algorithms in law.

The technology algorithms in law should be considered as a set of technological products (electronic documents, electronic digital signature, computer programs, search databases, electronic registers, electronic dispute resolution sites, legal bots, etc.) used in jurisprudence.

In turn, the rapid development of social relations in the postmodern era, the dynamics of technological development and information exchange processes, among other things, determine the special position and role of the electronic document in the system of document circulation of the present.

Key words: digitalization in legal sphere; transparency; legal algorithm; technology algorithms of law; electronic workflow; electronic document. 